\title{
MIASTA ŚRODKOWOEUROPEJSKIE
}

\section{SARAJEWO - ZAGRZEB - KRAKÓW. O MIEJSCACH OPUSZCZONYCH, ODRZUCONYCH I ODNALEZIONYCH NA AUSTRO-WĘGIERSKIEJ MAPIE BIOGRAFII IVO ANDRICIA}

\author{
SYLWIA NOWAK-BAJCAR ${ }^{1}$ \\ (Kraków)
}

\begin{abstract}
Słowa kluczowe: Ivo Andrić, Austro-Węgry, Sarajewo, Zagrzeb, Kraków, jugoslawizm, genius loci
\end{abstract}

Keywords: Ivo Andrić, Austro-Hungarian Empire, Sarajevo, Zagreb, Cracow, Yugoslavism, genius loci

\begin{abstract}
Abstrakt: Sylwia Nowak-Bajcar, SARAJEWO - ZAGRZEB - KRAKÓW. O MIEJSCACH OPUSZCZONYCH, ODRZUCONYCH I ODNALEZIONYCH NA AUSTRO-WĘGIERSKIEJ MAPIE BIOGRAFII IVO ANDRICIA. „PORÓWNANIA” 11, 2012, Vol. XI, ss. 193-203, ISSN 1733-165X. Na początku kwietnia 1914 roku Ivo Andrić, wówczas młody poeta, opuściwszy Bośnię po ukończeniu nauki w sarajewskim gimnazjum (1911), a następnie po krótkich epizodach studiów w Zagrzebiu (1912) i Wiedniu (1913), decyduje się na podjęcie nauki na krakowskim Uniwersytecie Jagiellońskim. Dlaczego konwencjonalny mieszczański świat, na pierwszy rzut oka nie tak przecież odmienny od opuszczonego przez Andricia świata salonów Zagrzebia i Wiednia, wydał się pisarzowi o bośniacko-chorwackich korzeniach, światem "lepszym”? Prezentując wybory pisarza $\mathrm{w}$ przededniu wybuchu pierwszej wojny światowej, przejawiające się zarówno w gestach odrzucenia, jak i w gestach afirmacji, pokazuję rolę, jaką w kształtowaniu się hybrydycznej, jugosłowiańskiej tożsamości twórcy odegrało spotkanie z polską kulturą początku XX wieku. Materiały dokumentalne stanowią punkt wyjścia do refleksji nad wpływem genius loci Krakowa na kształtowanie się intelektualnej sylwetki jugosłowiańskiego Noblisty (1892-1975).
\end{abstract}

Abstract: Sylwia Nowak-Bajcar, SARAJEVO - ZAGREB - CRACOW. ON DESERTED, DISCARDED AND REFOUND PLACES ON THE AUSTRO-HUNGARIAN MAP OF IVO

\footnotetext{
${ }^{1}$ Correspondence Address: s.nowak-bajcar@uj.edu.pl
} 
ANDRIĆ'S BIOGRAPHY. „PORÓWNANIA” 11, 2012, Vol. XI, pp. 193-203, ISSN 1733-165X. At the beginning of April 1914 Ivo Andrić, the young poet, after completing college education in Sarajevo (1911), and than after brief episodes of studies in Zagreb (1912) and Vienna (1913), decided to undertake studies at the Jagiellonian Univesity in Cracow. Why did conventional bourgeois world, at first glance not so different from world of salons in Zagreb and Vienna, seem to be a "better world" for the writer of Croatian-Bosnian roots? Presenting Andrić's choices on the eve of World War I, reflected in his gestures of rejection, as well as gestures of afimation, I show the role of meeting with Cracow and the Polish culture in formation of his hybrid Yugoslavic identity. Documentaries are the starting point for reflection on the influence of the genius loci of Cracow on the formation of the intellectual silhouette of the Yugoslavic Nobel-Prize winner (1892-1975).

W liście z 11 kwietnia 1914 roku do Mihovila Tomandla znaleźć można następującą wypowiedź Ivo Andricia o Krakowie: „Jestem tutaj oderwany od wszystkiego, co nasze. Zaklęte miasto: same muzea, grobowce i ołtarze; martwi królowie; niema sława i wrzeszczący żydzi"2 ${ }^{2}$ [podkreśl. - S.N.B.] Tydzień później 18 kwietnia 1914 roku do tego samego przyjaciela Andrić pisze: „Nie mogę powiedzieć, żeby moje życie tutaj było nudne, zupełnie przypadkowo weszliśmy ${ }^{3}$ do wyższych sfer, gdzie odnaleźliśmy wszystko to, o co gdzie indziej tak trudno: dobrych ludzi, błyskotliwe kobiety i świeże kanapki - gdyby nie zdrowie byłoby znakomicie"4.

Przejście od niezwykle przytłaczającego obrazu miasta w opisie pierwszych wrażeń o nim do stwierdzenia o "dobrych ludziach, błyskotliwych kobietach i świeżych kanapkach" oddaje zmianę nastroju Andricia, która dokonała się w ciągu kilku dni. Staje się ona jeszcze bardziej wyraźna w wypowiedzi pochodzącej z wywiadu, którego Andrić udzielił polskiemu dziennikarzowi w 1970 roku:

Wie Pan, czasem słyszałem i słyszę nieraz takie opinie o tym mieście, które odrzucam, które mnie obruszają. Że to miasto, owszem, piękne, stare, pełne muzeów i jak muzeum zamknięte i staroświeckie. Nigdy tak nie myślałem o mieście mojej młodości. Czułem się w Krakowie jak w nowoczesnym centrum pełnym życia, radości, wigoru. A że wdzięku dodawała mu cała historyczna oprawa, będąca klejnotem polskiej nauki i sztuki? To chyba nieźle? ${ }^{5}$

2 List I. Andricia do M. Tomandla z 11 kwietnia 1914 roku. „Sveske Zadužbine Ive Andrića” (Andrićevi davni prijatelji) 1986, nr 4, s. 15.

${ }^{3}$ Andrić wynajął w Krakowie mieszkanie wspólnie ze swoim kolegą V. Durbešiciem - jest tu mowa o ich obu.

${ }^{4}$ List Andricia do M. Tomandla z 18 kwietnia 1914 roku. „Sveske Zadužbine Ive Andrića” (Andrićevi davni prijatelji), op. cit., s. 16. Wykorzystane w niniejszym artykule fragmenty korespondencji Andricia oraz obcojęzycznej literatury przedmiotowej podaję w przekładzie własnym.

${ }^{5}$ Z. Targosz, Wywiad z Andriciem. „Przekrój” 1970, nr 1337, s. 7. 
Co w ciągu tych kilku dni wydarzyło się w życiu Andricia, wywołując tak nagłą zmianę w stosunku do miasta? Czym jest „nasze”, które odkrył on w austrowęgierskim, konserwatywnym Krakowie?

Udzielenie odpowiedzi na te pytania wymaga przypomnienia pewnych faktów z życia jugosłowiańskiego pisarza, urodzonego w Bośni, w rodzinie katolickiej w 1892 roku, w okresie swojego literackiego debiutu przed pierwszą wojna światową (w 1911 roku opublikował liryki w sarajewskim czasopiśmie „Bosanska vila", a w 1914 roku w antologii Hrvatska mlada lirika) związanego z chorwackim środowiskiem literackim zorientowanym projugosłowiańsko, od 1920 roku na stałe mieszkającego w Belgradzie (w Serbii). Kiedy na początku kwietnia 1914 roku przybywa on do Krakowa (aby opuścić go na wieść o zamachu na Franciszka Ferdynanda 28 czerwca 1914 roku), ma za sobą naukę w sarajewskim gimnazjum, które ukończył w 1911 roku, studia w Zagrzebiu w 1912 roku, a następnie w Wiedniu (od października 1913 roku).

Dlaczego zatem ów konwencjonalny galicyjski świat, nie tak przecież radykalnie odmienny od mieszczańskiego świata Zagrzebia czy Wiednia, który Andrić poznał i tak szybko - po kilku miesiącach - zdecydował się opuścić wydał się Andriciowi światem lepszym? Dlaczego Kraków - pomimo wilgoci, mgły i klimatu, który nie sprzyja osobom, jak Andrić, cierpiącym na gruźlicę - w odróżnieniu od Zagrzebia i Wiednia - wydał mu się miejscem "znośnym”, więcej nawet - idealnym, stał się jego utopią szczęścia?

Decyzja o wyjeździe do Krakowa wiąże się z powodami, dla których opuścił on Zagrzeb, nie mogąc w przestrzeni miasta odnaleźć i urzeczywistnić swojej wizji tego, co „nasze”. W jednym z listów wysłanych z Zagrzebia 22 stycznia 1913 roku do swojego przyjaciela - Vojmira Durbešicia Andrić, prawdopodobnie już wówczas biorąc pod uwagę możliwość zmiany miejsca studiów, pisze:

Pierwszy nieszczęsny poranek, zimny i grzeszny w tym bezlitosnym mieście wyznaczył granicę pomiędzy mną obecnym i mną niegdysiejszym; zerwałem ze wszystkim i jest mi ciężko. Na pewno nie jest ci obce to uczucie: powoli zapominasz (o smutku!) i sam powoli odchodzisz w niepamięć. - Mam wrażenie, że w ten oto sposób moje miasto wymazało mnie pamięci, i kocham je nieszczęśliwą miłością, kocham i staram się o nim zapomnieć. Sądzę, że każdy z nas powinien na zawsze pozostać w swoim mieście: podróżować, nigdy go nie opuszczając; każdy tęskni do dwóch czułych dłoni, dwóch dobrych skrzydeł o zmroku, każdy potrzebuje domu (o, nasza stara strzecho, na której gruchają gołębie!), Ja, i moi towarzysze, my tego nie mamy, jesteśmy wyklętymi skazańcami, naszym domem są ulica i knajpa, my się trujemy w miejscach publicznych, spożywamy strawę, nie dla nas przyrządzoną (o matczyna miłości!), śpimy w pościeli, która jest skalana (o upojna bielo poduszki i miękkości domowej pościeli!) i pijemy z kielichów, które są skażone, a ręce, które nas pieszczą, pieściły i pieścić będą innych (o, minione, młodzieńcze miłości pośród mroku mahali ${ }^{6}$, w drżącej poświacie lamp). Je-

${ }^{6}$ mahala (z tur.) - dzielnica wsi lub miasta 
dyna droga wiedzie coraz dalej na zachód i coraz głębiej w grzech, cierpienie i chorobę, a drogi powrotnej, na wschód, do domu nie widać; już nigdy nie znajdę ukojenia, nigdy nie zaznam cnoty niewiedzy ani ciszy niechcenia i piękna spokoju?

W tym dramatycznym wyznaniu, rejestrującym zagrzebski zwrot w życiu Andricia, wyznaniu mówiącym o osamotnieniu, stanowiącym konsekwencję opuszczenia Edenu bośniackiego dzieciństwa i poszukiwaniu miejsc, które wiodą coraz bardziej na zachód, z Zagrzebia do Wiednia, zawarta jest świadomość politycznej sytuacji Chorwacji. Troska Andricia, związana z wyborem drogi "na zachód” podkreśla dramatyzm sytuacji wielkiego kryzysu Austro-Węgier w obliczu pierwszej wojny światowej i dyskusji na temat celowości istnienia monarchii jako gwaranta równowagi pomiędzy Rosją, Francją i Niemcami. Próba przezwyciężenia politycznego i kulturalnego rozziewu pomiędzy Wschodem i Zachodem, zaowocowała marzeniami o wspólnym państwie Serbów i Chorwatów, ideą, której zagorzałym zwolennikiem stał się Andrić.

Początek XX wieku naznaczyły dyskusje poświęcone zasadności istnienia Austro-Węgier i emancypacji narodów słowiańskich. Zwolennicy utrzymania AustroWęgier zdecydowali się na zamianę koncepcji dualistycznej, trialistyczną (a więc utworzenie słowiańskiego państwa w ramach monarchii), podczas gdy jej przeciwnicy opowiadali się za utworzeniem niezależnego państwa słowiańskiego. Szczególna rola $\mathrm{w}$ tym drugim projekcie przypadła Serbii, która jako niezależne wówczas państwo posiadała potencjał,,aby stać się siłą konsolidującą narody południowosłowiańskie.

Udając się w drogę „na zachód” Andrić poszukiwał zatem tego, co „nasze”, a o tym właśnie celu nawet pod koniec życia wypowiadał się następująco:

Całe swoje życie opowiadałem się za zgodą i braterstwem. Byłem zwolennikiem jugoslawizmu już wówczas, kiedy musieliśmy walczyć o wyzwolenie naszej ojczyzny spod panowania Austro-Węgier. My, sarajewscy gimnazjaliści byliśmy przeciwnikami hegemonizmu jakiegokolwiek wyznania czy narodu (...). Nie chciałbym uchodzić za pyszałka, ale muszę wspomnieć o tym, że w Sarajewie byłem przewodniczącym postępowej organizacji młodzieży serbsko-chorwackiej. Nie byliśmy unitarystami, jak sądzą niektórzy, należałoby raczej powiedzieć, ze byliśmy panslawistami i zwolennikami internacjonalizmu a każdy kto posiada zdolność myślenia wie, że panslawizm i unitaryzm to nie to samo... Opowiadałem się za jugoslawizmem w 1941 roku, kiedy Partia Komunistów Jugosławii wprowadziła do niego - jak zresztą do wszystkiego - doktrynę marksistowską. Byłem zwolennikiem jugoslawizmu także w 1948 roku i jestem nim do dnia dzisiejszego - i prędzej umrę, niż na starość wyrzeknę się swoich przekonañ ${ }^{8}$. [podkreślenie moje - S.N.B.]

7 Ž. Poljak, Hrvatski književnik Ivo Andrić. Zagrebačko razdoblje na temelju neobjavljenih pisama s trideset i pet slika. Zagreb 2002, s. 59.

${ }^{8}$ Lj. Jandrić, Sa Ivo Andrićem 1968-1975. Beograd 1977, s. 73. 
Chociaż trudno precyzyjnie dookreślić sposób użycia przez Andricia terminów „panslawizm” i „internacjonalizm” - można raczej stwierdzić, że pisarz stosuje je w bliżej nieokreślonym znaczeniu, pozbawionym ich politycznych konotacji raczej może jako „słowiańską solidarność" i „kosmopolityzm”, wydaje się, że tego, czego spodziewał się znaleźć nie odnalazł podczas swoich studiów w Zagrzebiu w 1913 roku.

Potwierdzają to jego listy, w których padają wyjątkowo ostre słowa pod adresem Chorwacji - kraju i kultury, z którą w tamtym okresie Andrić się identyfikował. W liście do Vojmira Durbešicia z 1912 roku Andrić pisze:

Nie wiem, czy Chorwacja jest najbardziej pożałowania godnym krajem w Europie, ale wiem, że Zagrzeb jest najnędzniejszym miejscem w Chorwacji, ponieważ my, ponurzy i poważni synowie Południa, nie znajdujemy celu w tym toczonym od wewnątrz chorobą, alkoholicznym mieście, w którym tłuste dania usypiają ducha a wino mąci wzrok. Tutaj $\mathrm{w}$ ciągu roku człowiek staje się zwierzęciem $\mathrm{z}$ gatunku bestia zagrebiensis, $\mathrm{w}$ ciągu dwóch lat - szpiegiem9.

Z kolei w innym liście, z 1913 roku stwierdza: „Interesujące jest to alkoholiczne, toczone wewnętrzną chorobą miasto, interesujący jego mieszkańcy, a wszystko to razem - żałosne. Poznałem szacowne osobistości tego grodu: cała Croatia to tragedia, niema, niegodna uwagi a przez to jeszcze bardziej przerażająca"10. Pomimo ciężaru tych słów, z całą stanowczością należy podkreślić, że niepochlebne opinie na temat Zagrzebia nie stanowiły wówczas odosobnionego zjawiska. Podobny, kontrowersyjny charakter ma np. pochodząca z 1914 roku wypowiedź działacza jugosłowiańskiej młodzieży, Vladimira Čeriny, redaktora czasopism „Val” i „Vihor":

Spośród osiemdziesięciu tysięcy mieszkańców, jakich liczy sobie Zagrzeb pięćdziesiąt należałoby zaprowadzić do rzeźni, pięć tysięcy powinno znaleźć się w odmętach Savy, pięć kolejnych powininna zatopić jakaś niewyobrażalnie gwałtowna nawałnica, a pozostałą masę dwudziestu tysięcy należałoby umieścić $\mathrm{w}$ jakimś moralnym i narodowym purgatorium. (...) Temu miastu cyników należałoby siłą przeszczepić duszę i rozum miasta - Bohatera, jakim jest Belgrad $(\ldots)^{11}$.

Były one chrakterystyczne dla postaw radykalnej części postępowej młodzieży jugosłowiańskiej, wywodzącej się z Dalmacji - regionu rodzącego się na początku XX wieku centrum oporu przeciwko polityce lojalizmu i ugody ${ }^{12}$, zaś przeciwsta-

${ }^{9}$ List Andricia do Vojmira Durbešicia wysłany z Zagrzebia 30 grudnia 1912 roku, w: Ž. Poljak, Hrvatski književnik Ivo Andrić. Zagrebačko razdoblje na temelju neobjavljenih pisama s trideset $i$ pet slika. Zagreb 2002, s. 58 .

${ }^{10}$ List Andricia do Vojmira Durbešicia wysłany z Višegradu 20 marca 1913 roku. Ibidem, s. 63.

11 V. Čerina, U gradu cinika. „Vihor” 1914, nr 1.

12 Jak zauważa Mirjana Gross negatywny stosunek do Zagrzebia wyrażała przede wszystkim młodzież (jak Čerina) pochodząca z Dalmacji. Zob. M. Grass, Nacionalne ideje studentske omladine u Hrvatskoj uoči Proog svjetskog rata. Zagreb 1971, s. 139. Było to, jak należy przypuszczać, związane 
wianie Zagrzebowi Belgradu wiązało się z coraz silniejszą pozycją Serbii po wojnach bałkańskich. Choć żadne z młodzieżowych ugrupowań nie występowało przeciwko idei „wzajemności słowiańskiej” czy ideom zbliżenia narodowego, część działaczy sprzeciwiała się jednak temu, aby zbliżenie to wychodziło poza ramy współpracy kulturalnej i przechodziło $\mathrm{w}$ jedność polityczną. Zdecydowany opór takim unitarystycznym politycznym koncepcjom stawiały kręgi młodzieży skupionej wokół Antuna Gustava Matoša i czasopism „Mlada Hrvatska” oraz "Stekliš".

Niezadowolenie Andricia z atmosfery panującej w "niemej”, jak napisał, Chorwacji, mając na myśli zapewne politykę prowadzoną przez działaczy Koalicji chorwacko-serbskiej, których celem było zawarcie kompromisów z kolejnymi banami: Nikolą Tomašiciem, Slavko Cuvajem, Nikolą Skerlecem, dążenie do bardziej radykalnej akcji przeciwko Austro-Węgrom, a więc nastroje, które charakteryzowały całe młode młodobośniackie pokolenie), reakcje środowiska na reprezentowane przez Andricia jugosłowiańskie poglądy, konflikty ze środowiskiem artystycznym oraz z kręgami mieszczańskimi - konsekwencja kulturalnego nieprzystosowania Andricia, u źródeł którego leżały jego młodobośniackie korzenie (fakt, że środowisko to wywodziło się $\mathrm{w}$ większości $\mathrm{z}$ warstw chłopsko-rzemieślniczych niewątpliwie oddziaływało na jego kontestacyjną postawę wobec mieszczaństwa13) wpłynęły na podjęcie decyzji o opuszczeniu Zagrzebia.

Przywołane powyżej niezwykle kontrowersyjne fragmenty, poświęcone Zagrzebowi nie są jednak - jak je czytają niektórzy komentatorzy - wyrazem antychorwackiej postawy Andricia, ale stanowią wyraz bólu i rozczarowania, które miłości do Chorwacji nadawały piętno miłości nieszczęśliwej. Jej wyraz stanowią te najbardziej chyba liryczne listy Andricia, w których wyłożone są powody jego cierpienia. Do nich należą słowa skreślone do Vojmira Durbešicia na pocztówce ze zdjęciem pałacu bana Jelačicia, którego postać w symboliczny sposób przywołuje smutną historię chorwackiego zrywu narodowego (od jego euforii do porażki) w okresie Wiosny Ludów i po niej"14:

z intenesywnym rozwojem ruchu młodzieżowego w tym regionie. Po aneksji Bośni i Hercegowiny w 1908 roku powstają w Dalmacji warunki dla rozwoju ruchu młodzieżowego wymierzonego przeciwko Austro-Węgrom. W 1910 roku młodzież z Dalmacji i Przymorza z Franem Supilo na czele opowiada się za ideą jugosłowiańską, głosząc ideę zjednoczenia na gruzach Monarchii Habsburskiej. Pod nazwą Chorwacko-serbska Młodzież Postępowa (Hrvatsko-srpska napredna omladina) grupa ta w połowie 1911 roku występuje w Splicie z programem, w którym wyrażone zostają idee jedności serbsko-chorwackiej zarówno na planie współpracy kulturalnej, jak i na planie społecznym, oświatowym a nawet ekonomicznym. Część działaczy organizacji zniecierpliwiona zbyt zachowawczym charakterem jej działań i sceptyczna wobec koncepcji wywalczenia narodowych swobód metodą "pracy u podstaw" oraz ugodową polityką koalicji chorwacko-serbskiej, opuszcza szeregi postępowej młodzieży, tworząc grupę o nazwie Zjednoczenie Młodzieży Nacjonalistycznej (Ujedinjene nacionalističke omladine). J. Šidak, M. Gross, I. Karaman, D. Šepić. Povijest hrvatskog naroda 1960-1914. Zagreb 1968, s. 283.

13 Zob. V. Masleša, Mlada Bosna. Beograd 1945.

14 Postać bana J. Jelačicia stanowi symbol chorwackiej polityki podczas Wiosny Ludów, od początkowej euforii do jej upadku. Wykształcony w austriackiej Akademii Wojskowej Jelačić otrzymał 
Kochany! Do pozdrowień dołączam wizerunek tego pałacu w słynącej niegdyś z urody nieboszczki Chorwacji. Właśnie zakwitły oplatające jego ściany modre glicynie i wygląda jak sen o dawnych czasach. Jednak żal, że tamte czasy nigdy (przenigdy!) nie powrócą a ja usiłuję zrozumieć tych, którzy tak bardzo je opłakują. O Chorwacjo! $(\ldots)^{15}$.

To swoiste epitafium dla „świętej pamięci Chorwacji, pochowanej na zagrzebskim cmentarzu na Griču” zapisane w listach, będące dobitnym komentarzem jej sytuacji politycznej sygnalizuje oczywiście tylko jeden z powodów opuszczenia Zagrzebia przez Andricia. Drugim i - jak się wydaje - równie istotnym były nieporozumienia natury osobistej. Powody te, niestety, do dziś spowija woal tajemnicy, choć sam pisarz mówi o nich niedwuznacznie, jak chociażby w liście z Višegradu, z końca sierpnia 1913 roku, kiedy komentując swoje ówczesne doświadczenia, przywołuje zdanie Augusta Strindberga z powieści Czarne choragwie:

Zerwałem, nieważne z jakiego powodu, z wszystkimi przyjaciółmi, przyjaciółkami, partiami, kręgami i narodami. Urodziłem się w Travniku, przynależę do Sarajewa, dorastałem w Višegradzie. Nic mnie z nimi nie łączy, nie zachowałem w pamięci żadnych dobrych wspomnień (gdybym mógł, spaliłbym wszystko, co minęło, tak jak - przed kilku dniami - korespondencję), nie jestem kochany, gdyż nie mam zalet, które ceni sobie społeczeństwo. Mą duszę zdobi wieniec „z siedmiu grzechów głównych” i z siedmiu innych jeszcze, o istnieniu których Kościół dotąd nawet nie wiedział. Im więcej przyjaciół (i ach! przyjaciółek!) tym więcej potem problemów podczas rozstania (do którego zawsze przecież dochodzi). Skalałem się (...) paskudnymi aferami z różnymi kobietami, i nie pozostaje mi nic innego jak tylko mściwie powtarzać marne słowa pociechy cudownego pana Strindberga: Tak to jest, jak się człowiek wplącze w kobiece intrygi. Tak to jest... ${ }^{16}$

Decyzja o wyjeździe do Krakowa wiąże się z powodami, dla których Andrić opuścił Zagrzeb, nie mogąc w jego przestrzeni urzeczywistnić idei, które - według

tytuł bana w 1848 roku, w momencie przełomowym dla swojego narodu, kiedy ideami przewodnimi patriotycznego zrywu w walce o zjednoczenie ziem chorwackich (utworzenie Królestwa Chorwacji, Dalmacji i Slavonii, wprowadzenie języka chorwackiego jako urzędowego) były także idee równości społecznej. Godność tę powierzyli mu - w tajemnicy przed władzami węgierskimi - 23 marca 1848 roku, dwa dni przed oficjalnymi obradami Saboru - przedstawiciele reakcyjnej arystokracji węgierskiej i chorwackiej. Ta, obawiając się rozszerzenia się powstania na ziemie chorwacko-slawońskie, Jelačicia - oficera znanego w Krajinie, uznała za człowieka, który uniemożliwi realizację owych dążeń. Podczas gdy w pierwszej połowie 1848 roku Jelačić dąży do urzeczywistnienia narodowych i społecznych postulatów powstania ( 25 kwietnia 1848 roku zniesiona zostaje pańszczyzna) i nie podporządkowuje się władzom w Wiedniu i w Peszcie, w drugiej połowie tego roku Jelačić krwawo tłumi powstanie chłopskie i - po przejściu pod austriackie dowództwo - rewolucję na Węgrzech i w Vojvodinie. Po upadku Wiosny Ludów, w czasach absolutyzmu Bacha (1851-1859) Jelačić gorliwie realizuje politykę germanizacyjną. W. Felczak, T. Wasilewski, Historia Jugosławii. Wrocław - Warszawa - Kraków - Gdańsk - Łódź 1985, s. 322-334.

${ }^{15}$ List Andricia do V. Durbešicia z Zagrzebia z kwietnia lub maja 1913 roku, w: Ž. Poljak, op. cit., s. 66.

${ }^{16}$ List Andricia do V. Durbešicia z Višegradu, z końca sierpnia 1913 roku. Ibidem, s. 75 i 76. 
niego - przynależały do świata tego, co „nasze”. Wydaje się więc, że odnalazł on w Krakowie to wszystko, czego nie udało mu się odnaleźć w austro-węgierskim Zagrzebiu. W dotarciu do przyczyn fascynacji Andricia Krakowem (i Polską) pomocny wydaje się pochodzący z 1964 roku fragment niopublikowanego rękopisu, przechowywanego w Archiwum Serbskiej Akademii Nauk, w którym pojawia się niezwykle interesujący passus, dotyczący krakowskiego okresu studiów pisarza:

Ogarnięty przemożnym głodem intelektualnym, z wyostrzonymi zmysłami kroczyłem niegdyś ulicami tego miasta, w którym wszystko było dla mnie odkryciem [skreślone i poprawione na: odkrywałem - S.N.B]. [...] W bibliotekach, muzeach, teatrze, w dziennikach i periodykach, na wystawach sztuki współczesnej, stopniowo ukazywały mi się zarysy polskiej kultury, która na każdym kroku oczarowywała dążeniem do czystości i doskonałości formy, a szczególnie, ciągłością i konsekwencją swoich wysiłków wbrew wszystkiemu. Było to coś, za czym tęskniłem, czego nie mogłem odnaleźć w swoim kraju, ani w kulturach innych narodów słowiańskich, w tej mierze, w jakiej były mi one dostępne. Nie, niczego muzealnego, ani "stęchłego" nie było w żarliwych dyskusjach z moimi polskimi kolegami, ani w klarownych wykładach naszych profesorów, które uświadamiały mi, że odnalezienie środków wyrazu i właściwej formy możliwe jest tylko wówczas, gdy w człowieku istnieje potrzeba prawdziwego i szczerego wysiłku intelektualnego ${ }^{17}$ [podkreślenie moje - S.N.B.].

Na uwagę zasługuje tutaj zdanie - dodajmy, że w tekście maszynopisu zostało przez Andricia podczas redakcji tekstu wykreślone - zdanie mówiące o „ciągłości i konsekwencji polskiej kultury wbrew wszystkiemu”, których wówczas „nie mógł odnaleźć w swoim kraju, ani w kulturach innych narodów słowiańskich". Pozwalają one na dotarcie do powodów opuszczenia przez Andricia Chorwacji i zrozumienia złożoności jego osobistej, duchowej i politycznej bezdomności, która w najbardziej dramatyczny sposób dała o sobie znać podczas pobytu wówczas młodego poety w Zagrzebiu i w Wiedniu.

Wpływ „polskich studiów Andricia” na jego duchowy i intelektualny rozwój określa w znacznej mierze to, co nie mieści się w konwencjonalnych biogramach. Studia te nie odbywały się jedynie $w$ salach uniwersyteckich, ale przede wszystkim w kontakcie $\mathrm{z}$ atmosferą miasta, $\mathrm{w}$ kontaktach z ludźmi i z jego historyczną tkanką. Spotkanie z Krakowem należy więc postrzegać w kategoriach wpływu emocjonalnego. Największe znaczenie dla pochodzącego z Bośni Andricia miał fakt, że środowisko, w którym się obracał w tym mieście stanowili jego krajanie: Vilim Frančić, znany slawistom przede wszystkim jako autor Stownika serbochorwacko - polskiego ${ }^{18}$ i Gramatyki opisowej jezyka serbochorwckiego ${ }^{19}$, w okresie pobytu

17 I. Andrić, nieopublikowany rękopis nr 941. Archiwum Serbskiej Akademii Nauk i Sztuk, s. 39-40.

18 Przywołuję daty pierwszego wydania tomów słownika: V. Frančić, Stownik serbochorwackopolski. Warszawa 1956 (t. 1), 1959 (t. II).

19 Pierwsze wydanie gramatyki: V. Frančić, Gramatyka opisowa języka serbochorwackiego. Warszawa 1956. Drugie wydanie, uwzględniające nową ortografię z 1961 roku, z 1963 roku. 
Andricia w Krakowie w 1914 roku uczęszczający do Gimnazjum Św. Anny20, studiowali (Jovan Bijelić, Roman Petrović - uczniowie profesorów krakowskiej Akademii Sztuk Pięknych: Teodora Axentowicza i Leona Wyczólkowskiego'1) i - co niezwykle istotne - krąg jego polskich przyjaciół, który tworzyły rodziny reemigrantów z Bośni. Ojcowie owych szanownanych szlacheckich rodzin (m. in. rodzina Irzykowskich) pod koniec XIX wieku, stanowili po 1878 roku trzon wyższej kadry urzędniczej w Bośni ${ }^{22}$. Zdobywszy wykształcenie w Uniwersytecie Jagiellońskim, z chwilą ukończenia przez ich dzieci nauki w Gimnazjum sarajewskim, decydowali się jednak na dalsze ich kształcenie w kraju23.

Dzięki swoim rówieśnikom, z którymi łączyła go przestrzeń wspólnej pamięci o bośniackim dzieciństwie, Andrić wkroczył w świat na pierwszy rzut oka mar-

${ }^{20}$ V. Frančić (1896, Danuvar, Slavonia - 1978, Kraków) - którego ojczymem był Polak - Franciszek Trojan, przebywał w Krakowie od dzieciństwa. Od 1909 roku (klasy od I-IV), jak sam pisze w jednym $\mathrm{z}$ dokumentów przechowywanych w Archiwum Uniwersytetu Jagiellońskiego, uczęszcza do Gimnzajum św. Jacka w Podgórzu (które w 1915 roku zostało włączone w obręb Krakowa), chociaż jego nazwisko nie pojawia się w Sprawozdaniach Dyrektora tego gimnazjum z lat: 1910, 1911 i 1912. Od 1913 roku uczy się w Gimnazjum św. Anny (klasy: V, VI i VIII), a w VII klasie, a więc w 1915 roku uczęszcza do gimnazjum w Wiedniu. Maturę zdaje w krakowskim Gimnazjum św. Anny, w 1916 roku. Od 1916 do 1922 roku studiuje języki: polski i niemiecki w Uniwersytecie Jagiellońskim, a od 1917 roku, jeszcze w trakcie studiów, podejmuje w nim pracę na stanowisku lektora języka serbskochorwackiego. Archiwum Uniwersytetu Jagiellońskiego, Akta V. Frančicia, curriculum vitae, S II 619 i WF II 192, lektorat języka serbsko-chorwackiego. W 1940 roku, po zwolnieniu z obozu koncentracyjnego Sachsenhausen, w którym znalazł się wraz z grupą profesorów Uniwersytetu Jagiellońskiego i innych krakowskich instytucji, wywiezionych do niego oraz do Dachau przez faszystów (6 listopada 1939 roku), zwrócił się do Andricia - ówczesnego ambasadora Królestwa Jugosławii w Berlinie, prosząc o interwencję w celu ich uwolnienia. Zob. M. Barcik, Kronika Sonderacktion Krakau. „Alma Mater”, 2004, nr 64, http://www3.uj.edu.pl/alma/alma/64/01/03.html. O próbie uratowania krakowskich profesorów, zob. W. Natanson, Ivo Andrić a więźniowie obozów. „Twórczość” 1970, nr 4, s. 154.

21 Ślad tej znajomości stanowią szkice poświęcone twórczości malarzy: J. Bijelicia i R. Petrovicia. Zob. I. Andrić, Umetnik i njegovo delo. „Književne novine” 1957, nr 53 (18.10.1957), s. 1 i 4; Idem, Roman Petrović, „Izraz” 1959, nr. 5, s. 552-553.

22 Wówczas to Bośnia mocą postanowień Kongresu Berlińskiego, pozostając formalnie częścią Imperium Otomańskiego, przeszła $\mathrm{W}$ ręce administracji austro-węgierskiej. $\mathrm{W}$ celu stworzenia nowych struktur administracyjnych, które miały zastąpić przestarzały system turecki, do pracy w Bośni werbowana była inteligencja pochodzenia słowiańskiego, zyskujaca większą aprobatę lokalnej ludności, niż znienawidzeni "Szwabi”. W tym celu m.in. na Uniwersytecie Jagiellońskim i na Uniwersytecie Jana Kazimierza we Lwowie przeprowadzone były akcje, mające na celu pozyskanie absolwentów tych uczelni do pracy $\mathrm{w}$ tej odległej austro-węgierskiej prowincji. Formą rekompensaty za pracę w "trudnych warunkach" była możliwość szybkiej kariery. D. J. Gregorczyk, Misje księdza Macieja Czermińskiego SJ do Polonii bośniackiej w latach 1898-1909. „Studia Bobolanum” 2007, s. 47-64.

${ }^{23}$ Rodzinę Irzykowskich, u której Andrić zamieszkał podczas swojego pobytu w Krakowie oraz bośniacki epizod w historii jej członków przedstawiłam w referacie zaprezentowanym 15 września 2011 roku podczas konferencji "Ivo Andrić w literaturze serbskiej i w literaturach europejskich” zorganizowanej przez Międzynarodowe Centrum Slawistyczne w Belgradzie. S. Nowak-Bajcar, Jelena, žena koje nema i koje ima. Prilog proučavanaju krakovske biografie Ive Andrića, w: Ivo Andrić u srpskoj i evropskoj književnosti. Naučni sastanak slavista u Vukove dane 15-17.09.2011, Beograd 2012, s. 151-158. 
twego i zamkniętego Krakowa. Bośnia stała się dla niego przepustką do - jak mogło mu się wydawać - „lepszego świata” krakowskich salonów, w których nie brakowało „świeżych kanapek” i „błyskotliwych kobiet”.

Powróćmy jeszcze do słów Andricia zwierających jego wrażenia dotyczące Krakowa: "Zaklęte miasto: same muzea, grobowce i ołtarze; martwi królowie; niema sława i wrzeszczący żydzi." Opis osamotnienia w mieście, którego rozpoznawalnymi znakami były przeszłość $\mathrm{i}$ tradycja, jest $\mathrm{w}$ istocie zupełnie precyzyjną oceną niegdysiejszej stolicy Polski i atmosfery panującej w mieście pod koniec XIX i na początku XX wieku. Nieprzychylna diagnoza, wystawiona przez Andricia pod wpływem pierwszego kontaktu z miastem, opis jego „muzealności”: konserwatyzmu, stagnacji i zapatrzenia w przeszłość, są podobne do opinii, które na temat Krakowa wyrażali sami Polacy - mieszkańcy innych zaborów: rosyjskiego i pruskiego. Galicyjski Kraków pod austriacką okupacją jest - z jednej strony miastem takiej „stęchłej” atmosfery. Tworzyły ją nie tylko pamiątki przeszłości, wywołujące patriotyczne uniesienie $\mathrm{u}$ osób przybywających $\mathrm{z}$ innych części okupowanej Polski²4, ale także symbolika niegdysiejszej - do 18 wieku - stolicy Polski. Mianem owej „stęchłej” atmosfery określano także lojalistyczne tradycje polityczne, które od pierwszej połowy XIX wieku określiły kulturę polityczną miasta, ukształtowaną przez tendencje liberalne, które doszły do głosu w polityce AustroWęgier po wojnie z Włochami oraz po uzyskaniu przez Galicję autonomii w 1867 roku. Niektóre z celów polityki austriackiej, do których należała chęć osłabienia pozycji Rosji pokrywały się z oczekiwaniami Polaków.

Owa polityka liberalizacji i samorządowa niezależność miasta stwarzały możliwości i atmosferę, których nie było w innych zaborach, nie było ich także także w - przywołajmy jeszcze raz cytowane już wcześniej określenie Andricia - „niemej" Chorwacji. W Krakowie bowiem istniała możliwość publicznego wyrażania uczuć patriotycznych, które w innych częściach okupowanej Polski było czymś nie do pomyślenia ${ }^{25}$. Ów manifestowany patriotyzm i możliwość nieskrępowanego

24 Zob. W. Giełżyński, Budowanie niepodległej. Paryż 1985, s. 40.

${ }_{25}$ Podczas kongresu wiedeńskiego Kraków stanowił przedmiot zainteresowania trzech zaborców, dlatego w wyniku kompropmisu pomiędzy Rosją, Prusami i Austro-Węgrami, w okresie od 1815 do 1846 roku stał się formalnie niezależną republiką (Freistadt Krakau). Na początku XIX wieku dzięki znajdującym się tutaj pomnikom kultury ciągle był żywy romantyczny mit Krakowa - świętego miejsca Polaków, z Wawelem jako narodowym Panteonem, którego znaczenie potwierdzały uroczyste pogrzeby bohaterów z czasów Napoleona: księcia J. Poniatowskiego i T. Kościuszki w 1817 i 1818 roku. Stworzony w epoce romantyzmu mit Krakowa jako symbolu minionej wielkości nieistniejącego państwa, ale i symbol nadziei nie stracił na swojej sile także w późniejszym okresie. Gdy po upadku powstania listopadowego i styczniowego polskie ziemie zaboru rosyjskiego dotknęły drastyczne represje (m.in. zlikwidowano Uniwersytet Warszawski), a ziemie znajdujące się pod zaborem pruskim znalazły się w zasięgu germanizacyjnej polityki Bismarcka, Kraków stał się miejscem religijnopatriotycznych pielgrzymek: na Wawel z grobami królewskimi, do kościoła Mariackiego, na Skałkę z sarkofagami wybitnych obywateli miasta, na cmentarz Rakowicki z grobami zasłużonych Polaków, 
rozwoju kulturalnego miasta zapewniały wówczas Krakowowi status polskiego Piemontu. Fenomen Krakowa polegał więc wówczas na swoistym "paradoksie prowincjonalizmu" niegdysiejszej stolicy, która pozbawiona swoich funkcji, stała się duchową metropolią, kulturowym, naukowym i politycznym centrum Polski. Kraków nie tylko pełnił integracyjną rolę dla narodu, który był pozbawiony swojego państwa, ale - jak pisze o nim Jacek Purchla - pełnił także rolę „matecznika”. W nim na Uniwersytecie Jagiellońskim (oprócz lwowskiego, jedynej wyższej szkoły na ziemiach polskich z polskim językiem wykładowym) kształciły pokolenia Polaków, wśród nich polityków, które po wyzwoleniu w 1918 roku stanowiły trzon nowoczesnego polskiego społeczeństwa ${ }^{26}$.

Dla formującej się właśnie osobowości Andricia i jego jugosłowiańskich poglądów, Kraków - jak się wydaje - posiadał znaczenie szczególne - stał się dla pisarza urzeczywistnioną wizją patriotyzmu, w której szczególną rolę odgrywała integracyjna rola Krakowa jako centrum polskich ziem rozbitych przez zaborców. Po przybyciu do tego miasta Andrić zetknął się z mitem będącym wyrazem "potrzeby historii", mitem obecnym w myśli i intelektualnej postawie konserwatywnej szlachty - stanowiącej trzon krakowskiej inteligencji, ówczesnych profesorów Andricia i jego bliskich przyjaciół.

Świadomość krakowskiego prowincjonalizmu staje się więc kluczem do zrozumienia fascynacji tym miastem i do zrozumienia fenomenu odnalezionej w nim przez Andricia swojskości - a więc tej duchowej i intelektualnej przestrzeni, którą z Polakami podzielił pisarz wywodzący się z innej austro-węgierskiej prowincji Bośni, jakże odległej od środkowoeuropejskich centrów. Być może właśnie ów prowincjonalizm sprawił, że w odróżnieniu od odrzuconego Zagrzebia, który jawił się pisarzowi jako „niema tragedia”, Kraków - wbrew faktowi nieistnienia Polski na ówczesnej mapie Europy - przemówił siłą polskiego patriotyzmu i ciągłości polskiej kultury.

do pomnika Mickiewicza, pomnika Grunwaldzkiego czy na kopiec Kościuszki. Owo pielgrzymkowanie do pomników przeszłości stały się, jak pisze Purchla "patriotycznym nakazem i duchowym przeżyciem". J. Purchla, Matecznik polski. Pozaekonomiczne czynniki rozwoju Krakowa w okresie autonomii galicyjskiej. Kraków 1992, s. 36.

${ }^{26}$ Problematyce tej poświęcony jest w całości dorobek naukowy historyka sztuki Jacka Purchli. Ze względu na dużą ilość literatury przedmiotu, pozycję widniejącą $\mathrm{w}$ powyższym przypisie uzupełniam jedynie dwiema publikacjami krakowskiego badacza: J. Purchla, Kraków - prowincja czy metropolia? Kraków 1993; Idem, Krakau unter österreichischer Herrschaft 1842-1918. Faktoren seiner Entwicklung. Przeł. M. Miedziński, J. Czownicki. Wien 1993. 


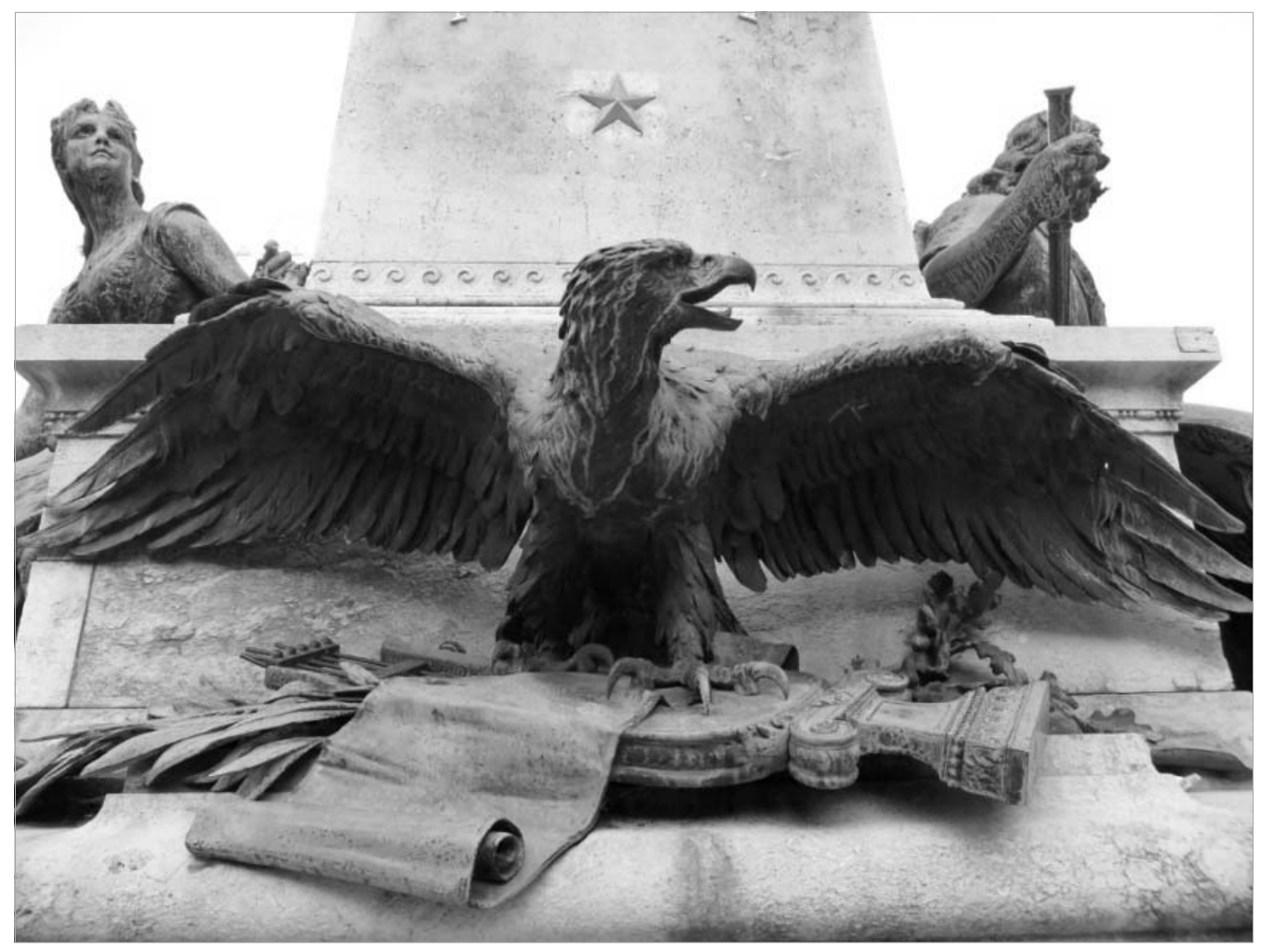

